\title{
A Biochemical and Morphologic Study of
} Very Low Density Lipoproteins in

\section{Carbohydrate-Induced Hypertriglyceridemia}

\author{
Neil B. Ruderman, Albert L. Jones, Ronald M. Krauss, and \\ ELEAzar Shafrur \\ From the Joslin Research Laboratory, Departments of Medicine and Anatomy, \\ Harvard Medical School and the Peter Bent Brigham Hospital and Diabetes \\ Foundation, Inc., Boston, Massachusetts 02215, and the Departments of \\ Medicine and Anatomy, University of California and the Veterans \\ Administration Hospital, San Francisco, California 94122
}

\begin{abstract}
A в S T R A C T On a high carbohydrate, fat-free diet, control and hypertriglyceridemic subject had a threefold increase in $d<1.006$, very low density lipoprotein (VLDL) triglyceride, and somewhat lesser increases in VLDL cholesterol and protein. Cholesterol and protein in $1.006<\mathrm{d}<1.21$ lipoprotein decreased in a reciprocal fashion, suggesting that these components might have been utilized in VLDL production. Electron microscope studies demonstrated a significant increase in the size of lipoprotein particles of the VLDL class and, in three of four subjects, an apparent increase in particle number. The change in particle size correlated with an increase in the triglyceride/protein ratio of the $d<$ 1.006 lipoprotein. Hypertriglyceridemic individuals differed from the control subjects in that they had greater absolute increases in VLDL triglyceride, cholesterol, and protein, and greater decreases in $1.006<\mathrm{d}<1.21$ cholesterol and protein. In addition, they had larger VLDL particles with a higher triglyceride/protein ratio, both before the study and at the peak of the carbohydrate effect. The data suggest that the increase in plasma triglycerides induced by a high carbohydrate diet is usually due to the appearance in plasma of both greater numbers of VLDL particles and larger particles that
\end{abstract}

This work was presented in part at the annual meeting of the American Federation for Clinical Research, Atlantic City, N. J., May 1969.

Dr. Shafrir was on sabbatical leave from the Hebrew University, Hadassah Medical School, Jerusalem, Israel. Dr. Ruderman's present address is: Metabolic Research Unit, Nuffield Department of Clinical Medicine, Radcliffe Infirmary, Oxford, England.

Received for publication 4 March 1970 and in revised form 3 February 1971. are relatively richer in triglyceride content than those isolated during the basal state.

\section{INTRODUCTION}

High carbohydrate low fat diets increase the concentration of plasma triglycerides in both normal and hypertriglyceridemic subjects (1-5). According to current theory, these diets cause protracted elevations of blood glucose and insulin (5-7) which in turn lead to an increased synthesis and release of triglyceride-rich very low density lipoproteins (VLDL) ${ }^{1}$ by the liver $(5,6$, 8-10). As far as is known, decreased triglyceride utilization by peripheral tissues is not a causative factor ( 7 , $9,10)$ although a decrease in postheparin lipolytic activity has been reported (11).

In this study, the mechanism of carbohydrate-induced hypertriglyceridemia was investigated in man, utilizing a combined biochemical and electron microscopic approach which we have previously used to study the regulation of hepatic (VLDL) production in the rat (12). Five normal individuals and four patients with endogenous hypertriglyceridemia were fed a high carbohydrate diet to increase their plasma triglyceride concentration. Serial measurements were made of the ratios of the lipid to protein constituents in VLDL, and of the size and relative number of lipoprotein particles within this fraction. From these data the thesis was evolved that carbohydrate-induced hypertriglyceridemia is usually due to the appearance in plasma both of a greater number of VLDL particles and of larger particles that are richer in triglyceride than those isolated

\footnotetext{
${ }^{1}$ Abbreviations used in this paper: VLDL, very low density lipoprotein; LDL, low density lipoprotein.
} 
TABLE I

Description of Experimental Subjects

\begin{tabular}{lccccc}
\hline Patient & Age & Height & Wt. & $\begin{array}{c}\text { \% of } \\
\text { Ideal } \\
\text { wt* }\end{array}$ & $\begin{array}{c}\text { Type of lipoprotein } \\
\text { electrophoretic } \\
\text { pattern } \ddagger\end{array}$ \\
\hline Control & & $c m$ & $k g$ & & \\
R. K. & 25 & 187 & 93 & +18 & \\
J. K. & 33 & 178 & 59 & -15 & \\
E. M. & 28 & 183 & 77 & +3 & \\
N. R. & 31 & 175 & 59 & -11 & \\
C. T. & 32 & 185 & 80 & +4 & \\
Hypertriglyceridemic & & & \\
P. C. & 33 & 175 & 85 & +22 & V $\S$ \\
P. D. & 43 & 172 & 93 & +37 & IV \\
E. L. & 31 & 169 & 79 & +21 & IV \\
J. L. & 33 & 169 & 72 & +10 & IV, V $\S$ \\
\hline
\end{tabular}

* 1959 Metropolitan Life Insutance Tables (23).

$\ddagger$ Classification of Fredrickson et al. (18).

$\S \mathrm{J}$. L.'s lipoprotein pattern was type $\mathrm{V}$ when first seen but reverted to type IV when he was placed on an isocaloric diet in which the fat content had been raised from 40 to $60 \%$ at the expense of carbohydrate. PC's plasma contained considerable numbers of chylomicra, even after a 36 hour fast, whereas J. L.'s plasma did not.

during low or normoglyceridemic periods. A preliminary report of part of this work has already appeared (13).

\section{METHODS}

Dietary studies. After an overnight fast, male normal volunteers (research fellows or medical students, Table I) who had been on their usual diets were placed on an isocaloric formula composed of Dexin ${ }^{2}$ (a partial starch hydrolysate containing $62 \%$ dextrins, $18 \%$ maltodextrins, and $19 \%$ maltose) and skimmed milk flavored with chocolate syrup. $^{3}$ In two studies ( $\mathrm{JK}, \mathrm{NR}_{3}$ ) Dextri-maltose ${ }^{4}$ a starch hydrolysate composed of dextrins and maltose) was substituted for. Dexin because the latter was no longer available. Both formulas were supplemented each day with a boiled potato and approximately 16 ounces of Coca Cola, making the final dietary composition: carbohydrate $85 \%$, protein $15 \%$, and fat $1 \%$. The diet was taken in three to five feedings. Subjects were maintained on this regimen for 8 days, during which time they were allowed to carry on the usual activities.

Four hypertriglyceridemic patients with normal glucose tolerance and normal levels of plasma postheparin lipolytic activity (14) were also investigated (Table I). Hepatic and renal disease, hypothyroidism and other causes of secondary hypertriglyceridemia were ruled out. Before the study, patients P. D. and E. L. were on the usual diets while patients P. C. and J. L. were on 1800 calorie reducing diets containing fat $(50 \%)$, carbohydrate $(30 \%)$, and protein $(20 \%)$. During the study all were maintained on a regimen

\footnotetext{
${ }^{2}$ Burroughs-Wellcome Co., Tuckahoe, N. Y.

${ }^{3}$ Hershey Co., Hershey, Pa.

"Mead Johnson Co., Evansville, Ind.
}

identical with that of the control group, except that their induction period was started after a $36 \mathrm{hr}$ fast to minimize the presence of chylomicra in the circulation. Two of the hypertriglyceridemic subjects (P. D. and E. L.) were induced while on a metabolic ward, and the remainder as outpatients. At the end of their induction period of 14 days, all of the patients in this group were fasted for 4 days in the hospital in order to acutely lower their plasma triglyceride levels. While on the diets, body weight did not differ from preinduction levels by more than $\pm 0.5 \mathrm{~kg}$ in any of the control or hypertriglyceridemic subjects.

Plasma analyses. Preprandial morning venous blood specimens were collected on at least 2 of every 3 study days. The blood was immediately placed in tubes containing $\mathrm{Na}_{2}$ EDTA, $1 \mathrm{mg} / \mathrm{ml}$ blood, and the red cells removed by centrifugation at $4^{\circ} \mathrm{C}$. Total plasma cholesterol was determined using the method of Chiamori and Henry (15), and triglycerides according to Carlson (16). Postheparin lipolytic activity was assayed in the hypertriglyceridemic patients while they were on their usual diets, as described by Biale and Shafrir (14). Intralipid emulsion ${ }^{5}$ was used as substrate. Lipoprotein electrophoresis was carried out according to Lees and Hatch (17), and the patterns classified as described by Fredrickson, Levy, and Lees (18). Intravenous glucose tolerance tests were performed as described by Soeldner, Gleason, Williams, Garcia, Beardwood, and Marble (19). Blood glucose was determined using an autoanalyzer:

Lipoprotein separation. A portion of plasma was layered under $0.15 \mathrm{M} \mathrm{NaCl}-1 \mathrm{~mm}$ EDTA $(\mathrm{d}=1.006)$ and centrifuged for $16 \mathrm{hr}$ at $40,000 \mathrm{rpm}$ (about $100,000 \mathrm{~g}$ ) and $10^{\circ} \mathrm{C}$ in the No. 50 rotor of a Spinco model $L$ ultracentrifuge. The metal parts of the tube cap were covered with a thin coat of silicone jelly to minimize adhesion of floating VLDL particles. After centrifugation, the tubes were sliced $1-1.5 \mathrm{~cm}$ from the top using a Spinco tube slicer. The milky VLDL rich layer was aspirated into a syringe and the tube cap was gently flushed with the $\mathrm{NaCl}-\mathrm{EDTA}$ solution to remove adherent VLDL. The VLDL collected in this way were then relayered under the $\mathrm{NaCl}$-EDTA solution and recentrifuged as before.

To determine whether VLDL isolated in this manner were contaminated with other plasma proteins, the washed VLDL were subjected to an additional centrifugation. There was no tendency of either the triglyceride/protein or cholesterol/protein ratio to increase. In four experiments these ratios varied within $\pm 8 \%$ (SD) of the value obtained after two ultracentrifugations.

The washed VLDL were analyzed for triglyceride and cholesterol. Protein content was determined by the method of Lowry, Rosebrough, Farr, and Randall (20). Since it was frequently slightly opalescent due to the presence of lipid, the final color solution in the protein assay was clarified by extracting twice with $3-4 \mathrm{ml}$ of heptane. Similar treatment of standard protein solutions did not result in loss of color.

A portion of the infranatant plasma obtained from the first ultracentrifugation was brought to a density of 1.21 by the addition of a concentrated $\mathrm{KBr}-\mathrm{NaCl}$ solution (21). It was then centrifuged for $16 \mathrm{hr}$ in the No. 50 rotor of the ultracentrifuge at $45,000 \mathrm{rpm}$ (about $120,000 \mathrm{~g}$ ). The lipoproteins which floated at this density range $(1.006<\mathrm{d}$

\footnotetext{
${ }^{5}$ Vitrum, Stockholm. Sweden.

- Technicon Co., Chauncey, N. Y.

${ }^{7}$ Beckman Instruments, Palo Alto, Calif.
} 
$<1.21$ ) were isolated by slicing the upper $1.0-1.5 \mathrm{~cm}$ portion of the tube. They were then recentrifuged under similar conditions and their protein content determined.

Electron microscopy. On several days during the study, 0.1-0.3 $\mathrm{ml}$ of fresh unrefrigerated plasma was fixed in phosphate-buffered $2 \%$ osmium tetroxide. A portion of the fixed plasma was then shadow-cast using the method described by Jones and Price (22). Particle diameter was determined on photographic enlargements of the electron micrographs. The shadowing procedure, as determined subsequently by comparing fixed and shadowed with fixed and unshadowed particles, added $\sim 150 \pm$ Ångstroms (A) to measured particle diameter. This was corrected for in all calculations. Particles which did not yield shadow lengths appropriate to their apparent diameter were omitted on the assumption that they were probably compressed or flattened during processing. Particles whose borders could not be delineated because of clumping were also discounted. Between 0 and $5 \%$ of particles were eliminated for these reasons. Visual estimates of particle number were based on comparisons of samples that had been diluted to the same degree.

TABLE II

Plasma Triglyceride and Cholesterol Levels in Control Subjects on High Carbohydrate Diet

\begin{tabular}{|c|c|c|c|}
\hline Subject & $\begin{array}{l}\text { Preinduction } \\
\quad \text { (day 0) }\end{array}$ & $\begin{array}{c}\text { Day of maximal } \\
\text { triglyceride } \\
\text { value } \\
\text { (day } 6 \text { or } 7 \text { ) }\end{array}$ & $\begin{array}{l}\text { End of induction } \\
\text { (day 8) }\end{array}$ \\
\hline \multicolumn{4}{|c|}{ Triglyceride, $\mu$ mole $/ 100 \mathrm{ml}$} \\
\hline R. K. & 72 & 196 & 196 \\
\hline J. K. & 108 & 143 & 108 \\
\hline E. M. & 116 & 187 & 161 \\
\hline N. R.1 & 73 & 200 & 128 \\
\hline 2 & $81\} 80 \ddagger$ & $113155 \ddagger$ & $89\} 108 t$ \\
\hline $3^{*}$ & 86 & 153) & 107 \\
\hline C. T. & 71 & 206 & 197 \\
\hline Mean $\pm \mathrm{SE}$ & $89 \pm 9$ & $177 \pm 12$ & $154 \pm 20 \S$ \\
\hline \multicolumn{4}{|c|}{ Cholesterol, $\mathrm{mg} / 100 \mathrm{ml}$} \\
\hline R. K. & 209 & 187 & 137 \\
\hline J. K. & 160 & 126 & 153 \\
\hline E. M. & 180 & 135 & 132 \\
\hline N. R.1 & 155 & 137 ) & 123 \\
\hline 2 & $164\} 160 \ddagger$ & $153149 \ddagger$ & $124\} 129 \ddagger$ \\
\hline $3^{*}$ & 162 & 158 & $139]$ \\
\hline C. $\mathrm{T}$. & 167 & 145 & 142 \\
\hline Mean $\pm \mathrm{SE}$ & $175 \pm 9$ & $148 \pm 10$ & $139 \pm 10 \|$ \\
\hline
\end{tabular}

* Received $25 \%$ of carbohydrate as fructose.

$\ddagger$ Value used in claculations.

\& Difference between maximal level of triglyceride and that recorded at end of induction, when calculated as a paired comparison, was $23 \pm 8(P=0.05)$.

$\|$ With subject $\mathrm{J}$. $\mathrm{K}$. excluded, the paired difference between the cholesterol level when triglyceride was at a maximum and the cholesterol level at the end of induction was $19 \pm 6(0.1$ $>P>0.05$ ).
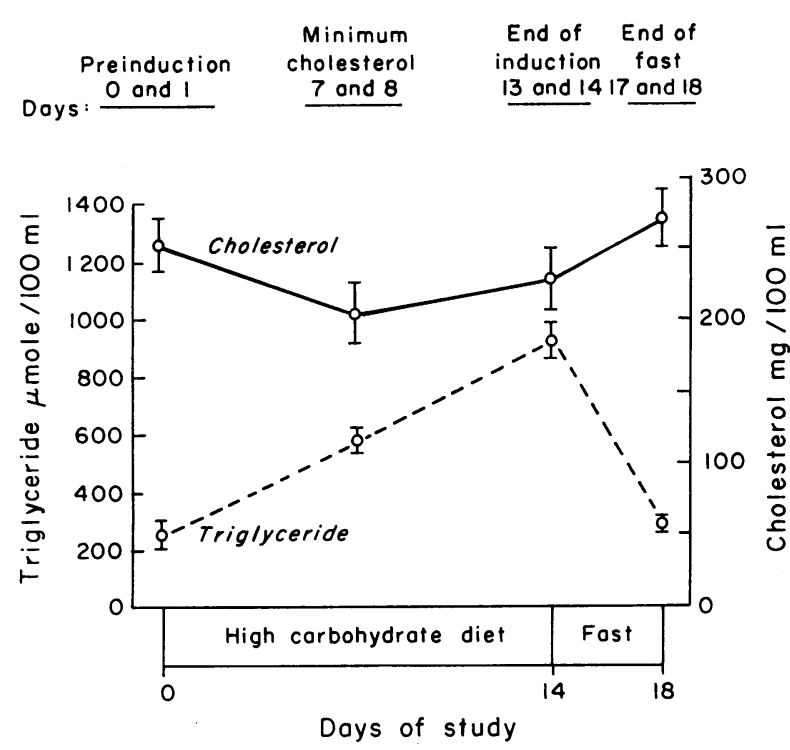

FIGURE 1 Changes in plasma triglyceride and cholesterol levels in three subjects with type IV hyperlipoproteinemia during carbohydrate induction and fasting. Each point and vertical bar represent the mean $\pm_{S E}$ of six determinations. See footnote to Table V. When calculated as paired comparisons, the differences in cholesterol values were statistically significant as follows: preinduction vs. minimum cholesterol : $47 \pm 8, P<0.001$; minimum cholesterol vs. end of induction; $24 \pm 8, P<0.05$ and end of induction vs. end of fast ; $41 \pm 9, P<0.01$.

Statistical analyses were based on group comparisons unless otherwise noted. Significance was determined using Student's " $t$ " test.

\section{RESULTS}

\section{Biochemical studies}

Plasma triglycerides. The effect of the high carbohydrate formula upon plasma triglyceride concentration is shown in Tables II and III, and Figs. 1-3. In control subjects, plasma triglycerides rose 1.5 - to 3 -fold, with peak levels occurring between the 6th and 7 th day (Table II, Fig. 2). In several individuals, triglyceride levels had already begun to fall by the end of the study.

Hypertriglyceridemic subjects were fasted for $36 \mathrm{hr}$ before starting on the diet. Despite this, they generally had basal triglyceride levels well above the mean of the control group (Table III, Figs. 1, 3). They also had far greater increases in plasma triglycerides during the study; with the exception of patient P. C., an individual who possibly had type $\mathrm{V}$ hyperlipoproteinemia, they failed to have a secondary fall. During a 4 day fast, triglyceride levels in the hypertriglyceridemic group returned toward preinduction concentrations; in no instance, however, did they return to normal.

Plasma cholesterol. Plasma cholesterol decreased initially in all subjects while on the high carbohydrate 
TABLE III

Plasma Triglyceride and Cholesterol Levels in Hypertriglyceridemic Subjects on High Carbohydrate Diet

\begin{tabular}{|c|c|c|c|c|c|}
\hline Patient & $\begin{array}{l}\text { Preinduction } \\
\quad(\text { day } 0)\end{array}$ & $\begin{array}{l}\text { Day of minimal } \\
\text { cholesterol value } \\
\text { (day } 7 \text { or } 8)\end{array}$ & $\begin{array}{l}\text { Day of maximal } \\
\text { triglyceride value } \\
\text { (day } 13 \text { or } 14)\end{array}$ & $\begin{array}{l}\text { End of induction } \\
\quad \text { (day 14) }\end{array}$ & $\begin{array}{l}\text { End of fast } \\
\text { (day 18) }\end{array}$ \\
\hline \multicolumn{6}{|c|}{ Triglyceride, $\mu$ mole $/ 100 \mathrm{ml}$} \\
\hline P. C. & 565 & 565 (day 15$)$ & 927 & 618 & 298 \\
\hline P.D. & 116 & 564 & 974 & 974 & 231 \\
\hline E. L. & 308 & 562 & 1156 & 1156 & 251 \\
\hline J. L. & 266 & 674 & 799 & 708 & 300 \\
\hline Mean $\pm \mathrm{SE}$ & $314 \pm 93$ & $591 \pm 28$ & $963 \pm 74$ & $844 \pm 123$ & $270 \pm 17$ \\
\hline \multicolumn{6}{|c|}{ Cholesterol, $\mathrm{mg} / 100 \mathrm{ml}$} \\
\hline P. C. & 261 & 175 (day 15$)$ & 224 (day 6) & 199 & 213 \\
\hline P. D. & 284 & 235 & 278 & 278 & 349 \\
\hline E. L. & 288 & 230 & 259 & 259 & 279 \\
\hline J. L. & 183 & 127 & 154 & 180 & 240 \\
\hline Mean $\pm \mathrm{SE}$ & $254 \pm 24$ & $192 \pm 26$ & $229 \pm 27$ & $229 \pm 23$ & $270 \pm 20$ \\
\hline
\end{tabular}

All subjects were on a high carbohydrate diet from day 0 to 14 . Between day 15 and 18 they were fasted. When calculated as a paired comparison, the mean difference $\pm \mathrm{SE}$ between cholesterol before induction and on the day plasma cholesterol was at a minimum was $62 \pm 11$. The mean difference between cholesterol levels at the end of the fast and at the end of the induction period was $41 \pm 14$.

formula. However, it did not vary in a simple inverse manner with plasma triglyceride. In the control group (Table II), cholesterol tended to decrease after the triglyceride concentration had reached its peak, although one individual ( $\mathrm{J} . \mathrm{K})$. had a secondary rise. In hypertriglyceridemic subjects (Table III, Fig. 1), plasma cholesterol reached its nadir before the triglyceride concentration had reached its maximum, and thereafter, it

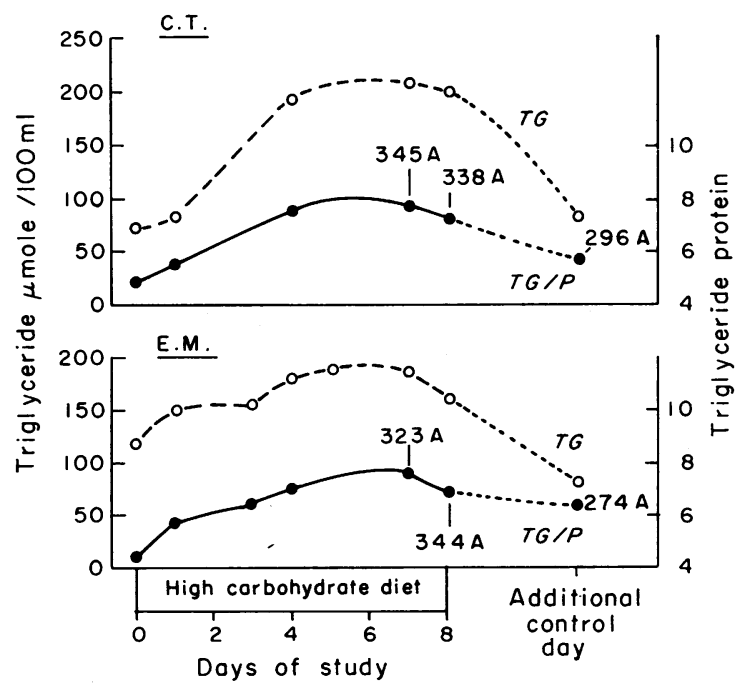

FIGURE 2 Relation between plasma triglyceride levels $(O)$, mean particle diameter (A) and the triglyceride/protein ratio (๑) of $\mathrm{d}<1.006$ lipoprotein in two control subjects on a high carbohydrate diet. returned toward preinduction levels. During the fast there was a pronounced rise in plasma cholesterol in all the hypertriglyceridemic subjects.

$V L D L$ composition. During carbohydrate induction, the ratio of triglyceride/protein and triglyceride/cholesterol of the VLDL fraction increased in all subjects (Table IV, Figs. 2, 3). In general, these changes correlated with the increases in plasma triglyceride and particle diameter (vide infra). Subject E. L. was somewhat atypical in that he had no increase in the triglyceride/protein ratio of his $\mathrm{d}<1.006$ lipoprotein between days 5 and 10 of the induction period despite the fact that his plasma triglyceride increased by more than $400 \mu$ mole $/ 100 \mathrm{ml}$. The significance of this observation remains to be established.

The hypertriglyceridemic patients had significantly higher triglyceride/protein ratios than the control group before induction, a finding which we have corroborated in a comparison of 10 control and 5 hypertriglyceridemic subjects $(4.65 \pm 0.28$ versus $6.48 \pm 0.13, P<0.001)$. This difference was maintained during the period of carbohydrate feeding although at higher ratios. During the fast, triglyceride/protein ratios returned to their preinduction levels as the plasma triglyceride concentration decreased.

To obtain an estimate of the absolute content of triglyceride, protein, and cholesterol in $\mathrm{d}<1.006$ lipoprotein, measured values had to be corrected for variable losses during isolation and washing. This was accomplished by assuming that VLDL contained $50 \%$ of 
TABLE IV

Compositional Changes in $d<1.006$ Lipoprotein during Carbohydrate Induction and Fasting

\begin{tabular}{|c|c|c|c|c|c|}
\hline & Preinduction & $\begin{array}{l}\text { Day of maximal } \\
\text { triglyceride value }\end{array}$ & End of fast & $\begin{array}{l}\text { Preinduction } \\
\text { vs. maximal tri- } \\
\text { glyceride }\end{array}$ & $\begin{array}{l}\text { Maximal tri- } \\
\text { glyceride vs. } \\
\text { end of fast }\end{array}$ \\
\hline \multicolumn{6}{|l|}{ Triglyceride protein ratio, $\mu$ mole $/ m g$} \\
\hline $\begin{array}{l}\text { Control (5) } \\
\text { Hypertriglyceridemic* }\end{array}$ & $\begin{array}{l}4.5 \pm 0.5 \\
6.2 \pm 0.3 \ddagger\end{array}$ & $\begin{array}{l}6.8 \pm 0.3 \\
9.3 \pm 0.3 \ddagger\end{array}$ & $5.9 \pm 0.3$ & $\begin{array}{l}P<0.01 \\
P<0.001\end{array}$ & $P<\overline{0.001}$ \\
\hline \multicolumn{6}{|c|}{ Triglyceride/cholesterol ratio, $\mu$ mole/mg } \\
\hline $\begin{array}{l}\text { Control (3) } \\
\text { Hypertriglyceridemic (8) }\end{array}$ & $\begin{array}{l}3.6 \pm 0.3 \\
4.3 \pm 0.2\end{array}$ & $\begin{array}{l}4.4 \pm 0.1 \\
6.3 \pm 0.3 \ddagger\end{array}$ & $4 . \overline{ \pm} \pm 0.6$ & $\begin{array}{l}P<0.05 \\
P<0.001\end{array}$ & $P<\overline{0.025}$ \\
\hline \multicolumn{6}{|l|}{ Cholesterol/protein ratio, $m g / m g$} \\
\hline $\begin{array}{l}\text { Control (3) } \\
\text { Hypertriglyceridemic (8) }\end{array}$ & $\begin{array}{l}1.7 \pm 0.0 \\
1.6 \pm 0.1\end{array}$ & $\begin{array}{l}1.5 \pm 0.1 \\
1.5 \pm 0.1\end{array}$ & $1.4 \pm 0.1$ & $\begin{array}{l}\text { NS } \\
\text { NS }\end{array}$ & $\mathrm{NS}^{-}$ \\
\hline
\end{tabular}

Number in parentheses indicates number used in experiment. Values are means $\pm \mathrm{SE}$ for indicated number of measurements.

* See footnote to Table V.

$\ddagger$ Significantly different from control, $P<0.05$.

plasma triglyceride when total plasma-triglyceride levels were less than $100 \mu$ mole $/ 100 \mathrm{ml}$, and that at higher triglyceride concentrations they contained all but 50 $\mu$ mole $/ 100 \mathrm{ml}$ of the triglycerides in plasma. These assumptions are based upon triglyceride distribution in lipoproteins of fasting subjects as reported in the literature (24) and from the maximum percentage of plasma triglycerides which we found in $d<1.006$ lipoprotein in the present study. The reported values for $d<1.006$ protein and triglyceride would have been approximately $25 \%$ lower if not for these corrections. Losses of this magnitude are unavoidable if it is desired to obtain a stable VLDL suspension by gentle procedures. More vigorous flushing of the centrifuge cap (see Methods) would probably have given more quantitative yields; however, it is associated with signs of VLDL disruption, such as clumping and freely floating lipid droplets.

The estimates of triglyceride, cholesterol, and protein content in $d<1.006$ lipoprotein are reported in Table V. During the period of formula feeding, the content of all three of these lipoprotein constituents increased in both normal and hypertriglyceridemic subjects. The absolute magnitude of the increases was substantially greater in the hypertriglyceridemic patients; the percentage increments, however, were similar in the two sets of subjects. In accord with the findings of earlier reports $(17,25,26)$, the hypertriglyceridemic patients had higher levels of VLDL triglyceride, cholesterol and protein before induction.

Composition of higher density lipoproteins. In both groups of subjects, the increase in VLDL protein during carbohydrate induction was associated with a significant decrease in the protein content of $1.006<\mathrm{d}<$
1.21 lipoprotein (Table VI). The decrease was more than sufficient to account for the entire increment in VLDL protein; in fact, it exceeded the latter to such an extent that a net decrease in total $\mathrm{d}<1.21$ lipoprotein protein was usually apparent. In general, changes in the

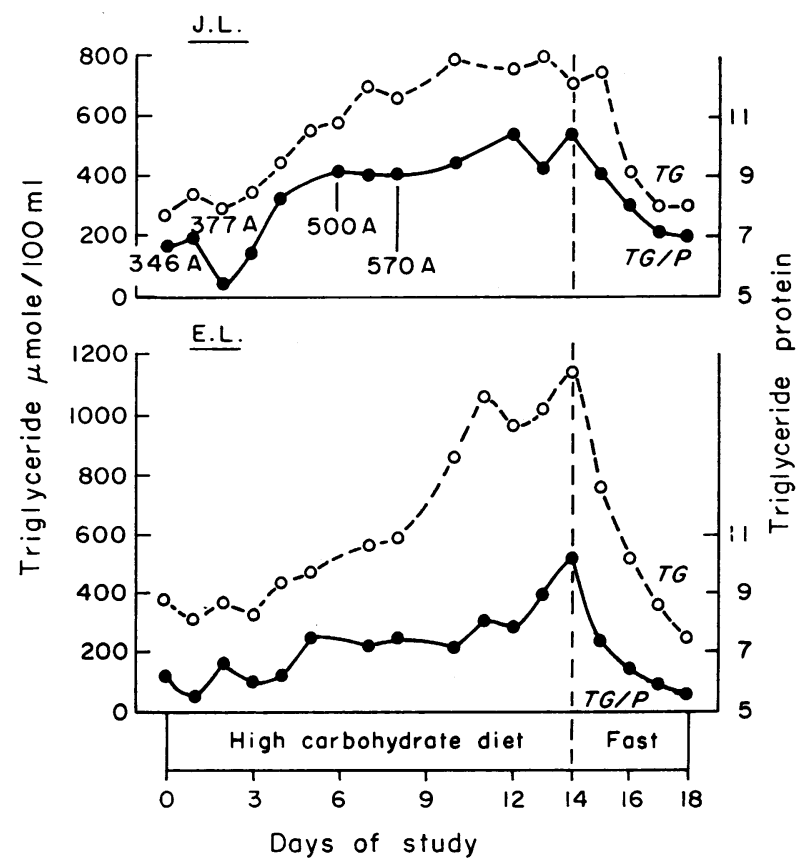

Figure 3 Relation between plasma triglyceride levels ( $O$ ), mean particle diameter (A) and the triglyceride/protein ratio (๑) of $\mathrm{d}<1.006$ lipoprotein in two hypertriglyceridemic subjects on a high carbohydrate diet and during a fast. 
TABLE V

Composition of $d<1.006$ (VLDL) Lipoprotein

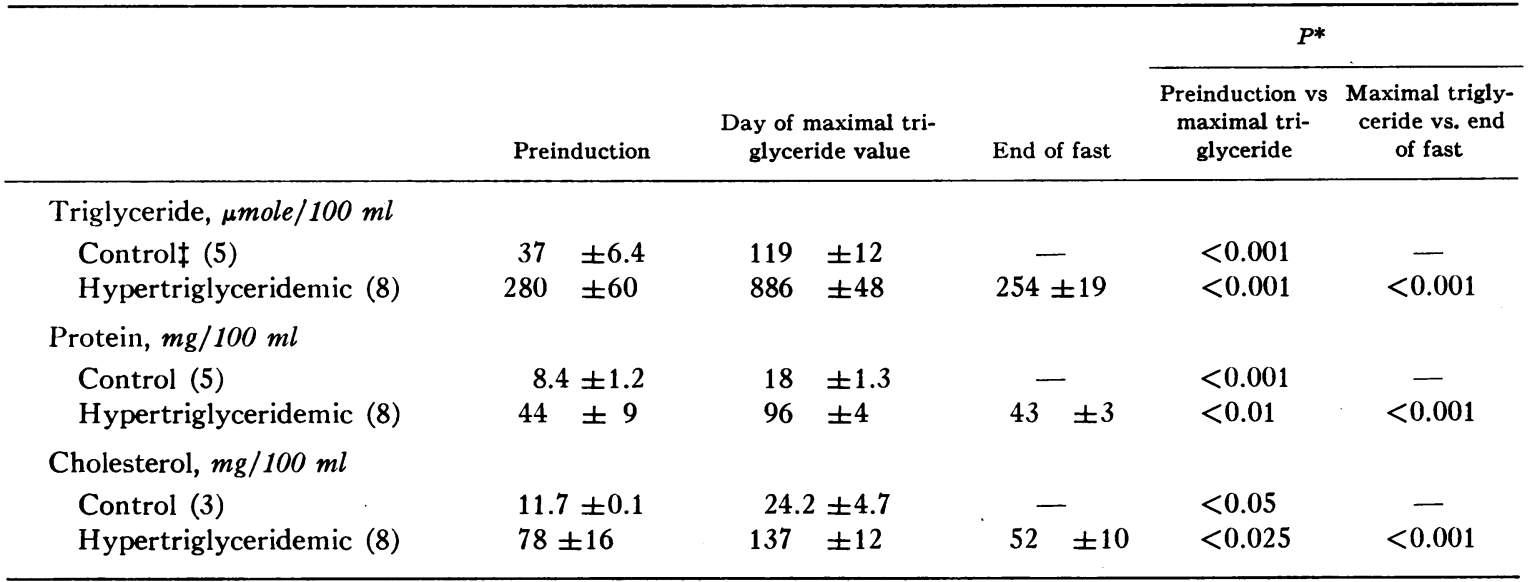

Number in parentheses indicates number used in experiment. Values are means $\pm \mathrm{SE}$ for the indicated number of measurements.

For each of the 4 hypertriglyceridemic subjects, preinduction values were taken from days 0 and 1 , end of fast values from days 17 and 18, and maximal triglyceride values from the 2 days on which plasma triglycerides were highest.

* Paired comparisons.

‡ Preinduction triglyceride values for control group do not correspond with values in Table II, since values for J. K. were obtained on a different control day. This was necessary as he had inadvertently eaten a fatty meal within 10 hours of his day 0 specimen and had an artifactually high triglyceride/protein ratio due to the presence of chylomicra in his circulation.

concentration of $1.006<\mathrm{d}<1.21$ and total plasma cholesterol roughly paralleled these changes in lipoprotein protein.

The hypertriglyceridemic patients had substantially greater decreases of $1.006<\mathrm{d}<1.21$ protein and cho- lesterol in association with the greater increases in these constituents in the VLDL fraction. It is of interest that their total $d<1.21$ protein decreased during induction because before the study their hypertriglyceridemia was associated with elevated levels of this fraction.

TABLE VI

Composition of $1.006<d<1.21$ Lipoproteins

\begin{tabular}{|c|c|c|c|c|c|c|}
\hline & \multirow[b]{2}{*}{ Preinduction } & \multirow[b]{2}{*}{$\begin{array}{l}\text { Day of maxi- } \\
\text { mal triglyceride } \\
\text { value }\end{array}$} & \multirow[b]{2}{*}{$\begin{array}{l}\text { End of in- } \\
\text { duction }\end{array}$} & \multirow[b]{2}{*}{ End of fast } & \multicolumn{2}{|c|}{$P^{*}$} \\
\hline & & & & & $\begin{array}{l}\text { Preinduction } \\
\text { vs. end of } \\
\text { induction }\end{array}$ & $\begin{array}{l}\text { End of in- } \\
\text { duction vs. } \\
\text { end of fast }\end{array}$ \\
\hline \multicolumn{7}{|c|}{$1.006<\mathrm{d}<1.21$ protein, $\mathrm{mg} / 100 \mathrm{ml}$} \\
\hline Control (5) & $226 \pm 25$ & $194 \pm 26$ & $175 \pm 26$ & - & $<0.005 \ddagger$ & - \\
\hline Hypertriglyceridemic (6) & $286 \pm 18$ & $199 \pm 26$ & $204 \pm 25$ & $294 \pm 48$ & $<0.005$ & $<0.025$ \\
\hline \multicolumn{7}{|c|}{ Total $\mathrm{d}<1.21$ lipoprotein protein, $\mathrm{mg} / 100 \mathrm{ml}$} \\
\hline Control (5) & $235 \pm 25$ & $208 \pm 22$ & $191 \pm 28$ & - & $<0.01 \ddagger$ & - \\
\hline Hypertriglyceridemic (6) & $341 \pm 15$ & $299 \pm 29$ & $291 \pm 33$ & $335 \pm 50$ & $<0.025$ & $<0.05$ \\
\hline \multicolumn{7}{|c|}{ Cholesterol in $1.006<\mathrm{d}<1.21$ lipoprotein $8, \mathrm{mg} / 100 \mathrm{ml}$} \\
\hline Control (3) & $158 \pm 3$ & $115 \pm 10$ & $107 \pm 2$ & - & $<0.001 \ddagger$ & - \\
\hline Hypertriglyceridemic (8) & $175 \pm 20$ & $79 \pm 9$ & $108 \pm 15$ & $189 \pm 21$ & $<0.005$ & $<0.005$ \\
\hline
\end{tabular}

Values are means $\pm \mathrm{SE}$ of indicated number of measurements. See footnote to Table V. Numbers in parentheses indicates numbers used in experiment.

* Paired comparisons.

¥ Paired comparison of Preinduction values vs values both at end of induction and at time triglyceride was maximum.

$\S$ Calculated by subtraction of $\mathrm{d}<1.006$ cholesterol from total plasma cholesterol. 
TABLE VII

Effect of High Carbohydrate Diet on Particle Size

\begin{tabular}{|c|c|c|c|c|c|c|c|c|}
\hline \multirow{4}{*}{$\begin{array}{l}\text { Particle diam- } \\
\text { eter (A) }\end{array}$} & \multicolumn{8}{|c|}{ Percent of total particles counted* } \\
\hline & \multicolumn{6}{|c|}{ Control } & \multirow{2}{*}{\multicolumn{2}{|c|}{$\begin{array}{c}\text { Hypertriglyceridemic } \\
\text { Patient P. C. }\end{array}$}} \\
\hline & \multicolumn{3}{|c|}{ Patient E. M. } & \multicolumn{3}{|c|}{ Patient C. T. } & & \\
\hline & Control day & Day 7 & Day 8 & Control day & Day 7 & Day 8 & Day 10 & 2 days fasted \\
\hline $170-230$ & 57 & 31 & 24 & 53 & 10 & 22 & 17 & 23 \\
\hline $230-260$ & 27 & 18 & 24 & 26 & 14 & 22 & 16 & 13 \\
\hline $260-$ & 17 & 51 & 53 & 21 & 76 & 56 & 67 & 64 \\
\hline \multicolumn{9}{|l|}{$\begin{array}{l}\text { Total number } \\
\text { of particles }\end{array}$} \\
\hline counted & 60 & 110 & 131 & 140 & 331 & 222 & 95 & 138 \\
\hline
\end{tabular}

Values are rounded off to the nearest whole number.

* Particles less than 170 A were visualized but were not counted.

\section{Electron microscopic studies}

The chemical data suggest that the increment in VLDL triglyceride probably did not result from a simple increase in the number of VLDL particles in plasma. This is evident from the fact that if particle composition were unchanged, the increment in VLDL protein would have accounted for only about $50 \%$ of the increment in VLDL triglyceride (Table V). This finding could be explained by an increase in particle size. It is widely held that triglyceride is distributed throughout the volume of the spherical VLDL particle, whereas, protein is distributed on the surface $(26-30)$. The relative volumes in which triglyceride and protein are distributed can therefore be calculated from the following expressions:

triglyceride distribution space (particle
$\quad$ core volume)

protein distribution space
$\quad$ cle coat volume)

where $\mathrm{d}$ here denotes particle diameter in Ångstrom(s) (A) and the average thickness of the surface coat is assumed to be 7 A $(26,29)$. From these equations it can be seen that an increase in particle diameter would be associated with a relatively greater increment in the distribution space of triglyceride than of protein. Indeed, Gustafson, Alaupovic, and Furman (27) have demonstrated that the concentration of triglyceride relative to protein in subfractions of $d<1.006$ lipoproteins is related to the size of the particles within the subfraction: the larger the particles; the higher the triglyceride to protein ratio.

\footnotetext{
${ }^{8}$ In essence this term behaves like the formula for the surface area of a sphere, i.e., $4 / 3 \pi r^{2}$.
}

To evaluate particle size in the present study, particle diameter was measured in the plasma of several subjects utilizing the electron microscope. In agreement with the findings of others $(27,31,32)$, we have found in a separate study that particles between 170-230 A are exclusively LDL and particles above $260 \mathrm{~A}$, almost exclusively VLDL. The 230-260 A group contained a mixture of the two subclasses with the LDL predominating (Jones, unpublished data). When calculating the diameter and volume of VLDL particles, the latter fraction was omitted. Omission of the 230-260 A particles could not have qualitatively altered the findings in any subject with the possible exception of patient P. C. Even here, a drastic increase in the percentage of VLDL particles in the fraction would have been required.

Relative numbers of $L D L$ and $V L D L$ particles. In accord with the chemical changes in $\mathrm{d}<1.006$ and $1.006<\mathrm{d}<1.21$ lipoprotein, there was an increase in the percentage of VLDL size particles at the expense of LDL particles during carbohydrate induction (Table VII). The changes were less striking in the hypertriglyceridemic subject, possibly because he had a high percentage of VLDL particles even when not induced. The proportion of particles between 230 and $260 \mathrm{~A}$ decreased somewhat in the two control subjects.

$V L D L$ size during induction. The mean diameter of VLDL size particles increased in all subjects during induction (Figs. 2-5, Tables VIII, IX). The increase was generalized. There was both a reduction in the relative number of small (260-325 A) particles and an increase in the number of larger ones. In addition, particles larger than any of those seen in the basal state were noted (Figs. 4, 5).

The hypertriglyceridemic patients had larger particles than the control subjects, before and after carbohydrate induction. Before induction, it was difficult to find a par- 

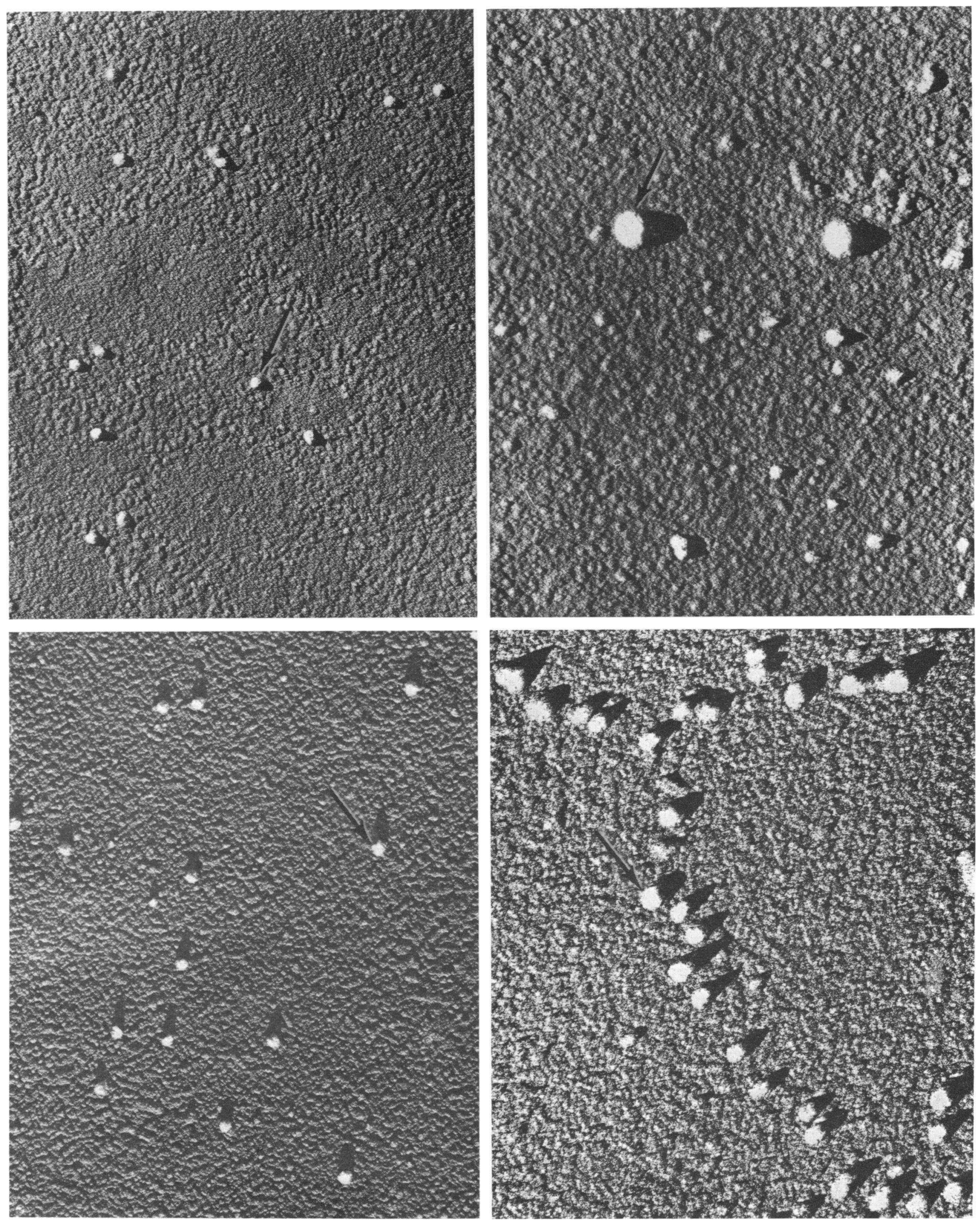
TABLE VIII

Effect of High Carbohydrate Diet on Diameter of Particles within the VLDL Fraction

\begin{tabular}{|c|c|c|c|c|c|c|c|c|}
\hline \multirow[b]{4}{*}{ Particle diameter (A) } & \multicolumn{8}{|c|}{ Percent of total particles counted } \\
\hline & \multicolumn{6}{|c|}{ Control } & \multirow{2}{*}{\multicolumn{2}{|c|}{$\begin{array}{c}\text { Hypertriglyceridemic } \\
\text { Patient P. C. }\end{array}$}} \\
\hline & \multicolumn{3}{|c|}{ Patient E. M. } & \multicolumn{3}{|c|}{ Patient C. T. } & & \\
\hline & Control day & Day 7 & Day 8 & Control day & Day 7 & Day 8 & Day 10 & 2 days fasted \\
\hline $260-275$ & 80 & 18 & 23 & 66 & 10 & 18 & 13 & 10 \\
\hline $275-325$ & 20) & 50 & 32 & 7 & 37 & 33 & 28 & 35 \\
\hline $325-375$ & & 21 & 36 & 24 & 36 & 30 & 26 & 32 \\
\hline $375-525$ & & 9 & 15 & 4 & 16 & 13 & 19 & 20 \\
\hline $525-675$ & & 2 & 6 & & 1.2 & 1.5 & 11 & 2 \\
\hline $675-825$ & & & & & 0.4 & & 1.5 & \\
\hline $825-$ & & & 1.5 & & & & & \\
\hline Number of particles & & & & & & & & \\
\hline counted & 10 & 56 & 69 & 29 & 250 & 125 & 64 & 88 \\
\hline Mean particle & & & & & & & & \\
\hline diameter (A) & 274 & 323 & 344 & 296 & 345 & 338 & 367 & 346 \\
\hline
\end{tabular}

Values above $2 \%$ are rounded off to the nearest whole number.

ticle larger than $375 \mathrm{~A}$ in the plasma of either control subjects, whereas, more than $20 \%$ of the particles in the plasma of subjects P. C. and J. L. (Fig. 5) were in this range. After induction, a variable but significant proportion of particles in the plasma of the control subjects were $375 \mathrm{~A}$ or greater, including a small percentage above $525 \mathrm{~A}$. Only one particle above $825 \mathrm{~A}$ was noted of the more than 500 measured. In contrast, $10 \%$ of the particles in subject J. L.'s plasma were $825 \mathrm{~A}$ or greater incuding several larger than 1000 A. Particles of the latter dimensions were also noted in the plasma of subject P. D. on a day when his plasma triglyceride level was $974 \mu \mathrm{mole} / 100 \mathrm{ml}$ and the triglyceride/protein ratio of his VLDL was 9.8.

There was not sufficient morphologic data to permit accurate quantitative measurements of particle diameter and volume (i'ide infra) in several of the hypertriglyceridemic subjects. Nevertheless, qualitative observations, coupled with the fact that subjects P. D. and E. L. had markedly elevated triglyceride/protein ratios throughout the study. makes it very likely that their particles were considerably larger than those of the control subject.
TABLE IX

Effect of High Carbohydrate Diet on Diameter of VLDL Particles in Hypertriglyceridemic

Subject J. L.

\begin{tabular}{ccrrr}
\hline & \multicolumn{4}{c}{ Percent of total particles counted } \\
\cline { 2 - 5 } Particle diameter (A) & $\begin{array}{c}\text { Control } \\
\text { day }\end{array}$ & Day 1 & Day 6 & Day 8 \\
\hline $260-275$ & 14 & 10 & 4 & 3 \\
$275-325$ & 35 & 24 & 13 & 11 \\
$325-375$ & 24 & 22 & 9 & 9 \\
$375-525$ & 27 & 31 & 40 & 26 \\
$525-675$ & 1.1 & 1 & 10 & 19 \\
$675-825$ & 0.4 & & 7 & 10 \\
$825-$ & & & & \\
Number of particles & & & & 10 \\
counted & 282 & 105 & 199 & 100 \\
Mean particle & & & & \\
diameter & 346 & 377 & 500 & 578 \\
\hline
\end{tabular}

Values above $2 \%$ are rounded off to the nearest whole number.

Figure 4 Electron micrographs of plasma lipoprotein particles in two control subjects. $\times 60,000$. Lower panel: C. T. Before induction (left) a homogenous population of 400 to $450 \mathrm{~A}$ (arrow) particles are seen (diameter including shadowing artifact). After 7 days on a ligh carbohydrate diet (right), there is a generalized increase in particle number. The particle in the postinduction specimen indicated by the arrow is $700 \mathrm{~A}$. Upper panel: $\mathrm{E}$. M. Particles in the preinduction specimen (left) are 350 to $400 \mathrm{~A}$ (arrow) in diameter. After 8 days of formula feeding, particle diameter varies over a much wider range (right) and a few large particles are seen. The $1150 \mathrm{~A}$ particle (arrow) seen in the postinduction specimen was the largest seen in any control subject. 

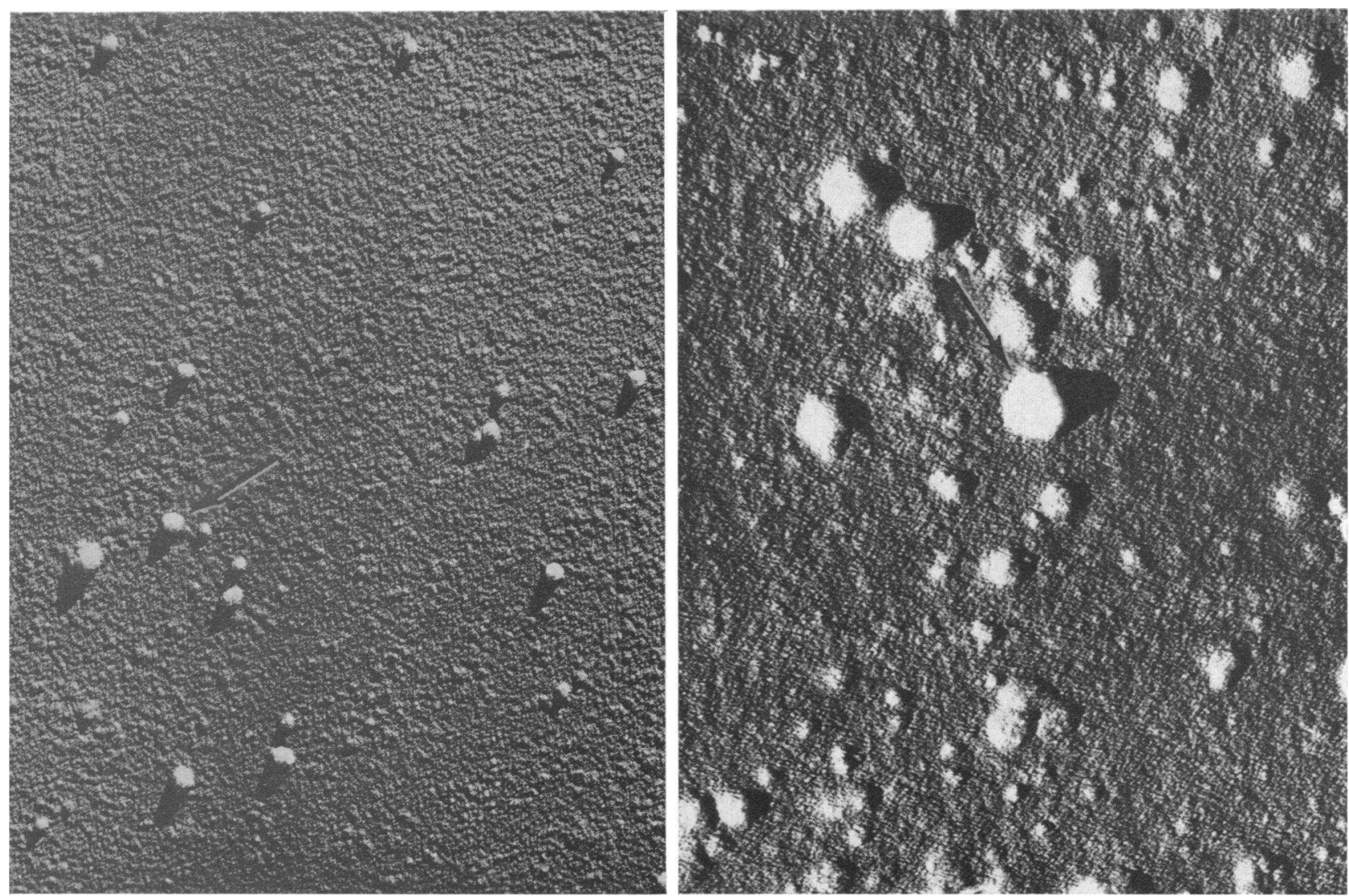

Figure 5 Plasma lipoprotein particles of patient J. L. The plasma is $\sim 2$ times more dilute than that of the control subjects show in Fig. 5. Before the study (left), there is a heterogeneous population of particles with particle diameter varying between 300 and $700 \mathrm{~A}$. The arrow points to a particle of $500 \mathrm{~A}$. After 8 days of high carbohydrate feeding (right), numerous particles of chylomicron proportions are noted. The particle indicated by the arrow is 1450 A. $\times 60,000$.

Particle number. Increased numbers of VLDL particles were consistently seen in the plasmas of the control subjects after induction (Fig. 4, Tables VII, VIII). It was difficult to determine whether a similar phenomenon occurred in the hypertriglyceridemic subjects since they had a very large number of particles in their plasma even before induction; in fact, their plasma frequently had to be diluted several times more than that of the control subjects in order to achieve adequate resolution of the individual particles.

The above observations suggest that the high carbohydrate diet increased the number, as well as the size of plasma VLDL particles in the control subjects. They also suggest that the hypertriglyceridemic patients had a greater number of particles than the control subjects when both were in the basal state. To evaluate these points further, the extent to which the differences in VLDL triglyceride and protein in these situations could be attributed to the difference in particle volume was calculated (Table X). Presumably, that portion of the difference not accountable for by the disparity in volume would reflect a difference in particle number.

The results obtained in this way must be regarded as semiquantitative since the $230-260$ A fraction was omitted and because the inclusion of too few or too many very large particles could markedly alter the results. Despite these limitations, a reasonably clear-cut and consistent picture emerged in each subject. The data reveal that the increase in particle volume only accounted for part of the induction increment in VLDL triglyceride and protein in the two control subjects and patient P. C. Likewise, less than $30 \%$ of the preinduction difference in VLDL triglyceride and protein between control and hypertriglyceridemic subjects could be attributed to the differences in particle volume. These findings, therefore, confirm the impression of increased particle number gained by direct visualization of the fixed plasma.

Subject J. L. was exceptional in that his increase in particle volume during induction was more than suff- 
TABLE X

Relationship Between Changes in Particle Volume and the Increment

in VLDL Triglyceride $(T G)$ and Protein

\begin{tabular}{|c|c|c|c|c|c|c|c|}
\hline Patient & Day of study & TG & $\begin{array}{l}\text { Mean particle } \\
\text { core volume }\end{array}$ & $\begin{array}{l}\text { Per cent TG } \\
\text { increment due } \\
\text { to volume }\end{array}$ & Protein & $\begin{array}{l}\text { Mean particle } \\
\text { surface volume }\end{array}$ & $\begin{array}{l}\text { Per cent } \\
\text { protein incre- } \\
\text { ment due to } \\
\Delta \text { volume }\end{array}$ \\
\hline & & $\begin{array}{l}\text { umole/ } \\
100 \mathrm{ml}\end{array}$ & $A \times 10^{-6}$ & & $\mathrm{mg} / 100 \mathrm{ml}$ & $A \times 10^{-6}$ & \\
\hline \multicolumn{8}{|l|}{ Controls } \\
\hline \multirow[t]{3}{*}{ E. M. } & $*$ & 43 & 9.3 & & 6.4 & 1.6 & \\
\hline & 7 & 134 & 18 & 44 & 17.7 & 2.3 & 25 \\
\hline & 8 & 111 & $22.8(18.4) \ddagger$ & $101(62) \ddagger$ & 16.1 & $2.5(2.4) \ddagger$ & $37(33) \ddagger$ \\
\hline \multirow[t]{3}{*}{ C. T. } & * & 42 & 12.7 & & 7.9 & 1.9 & \\
\hline & 7 & 156 & 20.2 & 22 & 20.5 & 2.5 & 20 \\
\hline & 8 & 147 & 18 & 18 & 19.9 & 2.3 & 14 \\
\hline \multicolumn{8}{|c|}{ Hypertriglyceridemic } \\
\hline \multirow[t]{4}{*}{ J. L. } & 0 & 216 & 28 & & 32.3 & 2.6 & \\
\hline & 1 & 284 & 40 & 138 & 41.2 & 3.4 & 109 \\
\hline & 6 & 526 & 89 & 152 & 57.9 & 6.1 & 169 \\
\hline & 8 & 624 & 125 & 183 & 69.3 & 8.0 & 182 \\
\hline \multirow[t]{2}{*}{ P. C. } & 10 & 798 & 32.1 & 36 & 102 & 3.8 & 29 \\
\hline & 16 (day 2 fast) & 307 & 20.4 & & 62.5 & 3.2 & \\
\hline
\end{tabular}

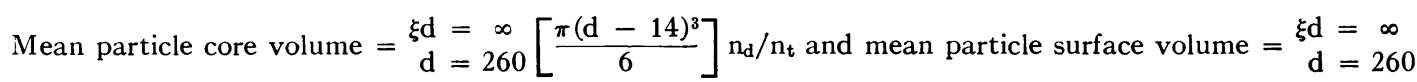

$\left[\frac{\pi d^{3}}{6}-\frac{\pi(d-14)^{3}}{6}\right] n_{d} / n_{t}$ where $d=$ particle diameter in $A n_{d}=$ number of particles of diameter $d$ and $n_{t}$

$=$ total number of particles counted.

* Specimen taken on a control day several weeks after the termination of the study (See Fig. 2).

$\ddagger$ Parenthetical result obtained if one unusually large particle of $850 \mathrm{~A}$ was omitted from the calculations.

cient to account for the entire increment in his VLDL protein and triglyceride. The reason for the difference between patients J. L. and P. C. was not apparent. It remains to be determined whether it reflects a different basis for the hypertriglyceridemia in the two patients.

\section{DISCUSSION}

It has long been appreciated that fat-free high carbohydrate diets cause a marked elevation in plasma triglycerides (1-5). The data presented here suggest that this rise is usually due to the apparence in plasma of both greater numbers of VLDL particles and of particles that are larger and relatively richer in triglyceride than those found in the basal state. In one subject with hypertriglyceridemia, however, the increment in VLDL triglyceride could be accounted for solely on the basis of an increase in particle size.

The reason for the appearance of large particles during carbohydrate induction is a matter of interest. Several studies in animals and man indicate that hypertriglyceridemia, due to carbohydrate induction, results from increased hepatic triglyceride production and release
$(6,9,10)$. This raises the question: does the liver produce the larger particles with increased triglyceride content only when it is synthesizing triglyceride at a high rate, or, does it normally produce such particles? In the latter case, the particles might not be seen in plasma unless the capacity of peripheral tissues to utilize lipoprotein triglyceride is overloaded.

Which of these explanations is correct cannot be determined at present; certain animal studies, however, suggest that the liver does produce larger VLDL particles when triglyceride synthesis is stimulated. We have found that perfusion of a rat liver with a free fatty acidrich medium causes an increase in triglyceride output which is, in part, due to an increase in the size of the VLDL particles released by the liver (12). As in this investigation, an increase in the triglyceride/protein ration of the VLDL fraction was observed. In another study, Windmueller and Spaeth (33) noted that perfused livers obtained from fasted-refed rats released triglyceride at two and one-half times the rate of livers from animals fed ad libitum. They did not determine particle size directly; they observed, however, that the triglyceride/phospholipid ratio in the $\mathrm{d}<1.016$ frac- 
tion of the perfusate from the fasted-refed group was two times higher, indicating that the livers of these animals were releasing larger lipoprotein particles (27). Finally, Mahley, Hamilton, and LeQuire demonstrated that the VLDL isolated from the Golgi apparatus of rat liver are morphologically (Hamilton, personal communication) and chemically (34) very similar to plasma VLDL isolated from the same animals. This suggests that, at any given time, most of the VLDL particles in the circulation have not been substantially altered in composition since leaving the liver.

The above mentioned studies suggest that in the rat, large VLDL particles with an increased triglyceride content can result from excessive rates of hepatic triglyceride synthesis. It remains to be seen whether this is the case in man, particularly in the pathologic situation of type IV hyperlipoproteinemia, where such particles have been found in the circulation, both before and after carbohydrate induction (references 26, 35, 36, and this study).

Particles above $800 \mathrm{~A}$ in diameter accounted for a significant percentage of the increment in particle volume in patient J. L. (days 6 and 8 ). They were of no importance in any of the control subjects or in hypertriglyceridemic subject $P$. C. It has been previously demonstrated that rat liver can produce VLDL particles of this size if triglyceride synthesis is sufficiently stimulated (12). Although in the present study, all subjects were on essentially fat-free diets, the possibility that some of the larger VLDL particles and perhaps even some of the smaller ones were produced by intestine rather than liver cannot be excluded. Conceivably, the intestine could have synthesized triglyceride from fatty acids derived from the hydrolysis of bile phospholipids and triglycerides (37) or from fatty acids it had synthesized itself (38). The studies of Windmueller and Levy (39) suggest that lipoprotein of intestinal origin can account for $10 \%$ of total VLDL production in rats on a fat-free diet. Ockner, Hughes, and Isselbacher (40) have suggested that intestinal synthesis may account for an even greater proportion of VLDL production in a fasting rat. The quantitative importance of intestinal VLDL production in man is not known.

In addition to having larger VLDL particles, the hypertriglyceridemic subjects also had a greater number of VLDL particles in their circulation; in fact, before induction, differences in particle number accounted for a greater part of the disparity in triglyceride levels between the two groups than did the differences in particle volume. Increased numbers of particles were also found in the two control subjects at the peak of induction and accounted for the major part of the increase in their VLDL triglyceride. As is the case with the increase in particle size, it remains to be determined whether these increases in particle number reflect hepatic overproduction, peripheral underutilization, or a combination of the two.

Electron microscopic studies of liver may prove helpful in solving the problem since overproduction of hypertriglyceridemia in animals is associated with an increased number of VLDL particles in intracellular organelles and in the space of Disse. To date, this has been demonstrated in animals who were hypertriglyceridemic because of nephrosis," anti-insulin serum injection (41), cortisone treatment (42), and ethanol administration (43).

The protein and cholesterol content of VLDL rose substantially as plasma and VLDL triglyceride increased. The observation that these constituents decreased in a reciprocal fashion in higher density lipoproteins suggests that they may have been utilized in the production of VLDL. Such a possibility would seem to be compatible with the evidence on the presence of $\alpha$ and $\beta$-apoprotein peptides within the structure of VLDL (18). It is also in accord with the observation of Lees and Fredrickson (35) that the rise in plasma triglycerides during carbohydrate induction is associated with a decrease in the staining intensity of the $\alpha$ - and $\beta$-bands in a lipoprotein electrophoretogram.

The decrease of cholesterol and protein in the $1.006<$ $\mathrm{d}<1.21$ lipoprotein fraction was greater than the increment of these constituents in the $\mathrm{d}<1.006$ fraction suggesting that an additional factor may have been influencing their metabolism. In this regard, the observed decrease in total plasma cholesterol is of interest. As reviewed by MacDonald (44), several investigators have reported that fat-free, high-carbohydrate diets lower plasma cholesterol levels. It has been suggested that this effect is related to the ingestion of large quantities of certain carbohydrates rather than to a lack of any dietary constituent, since cholesterol levels can be restored to normal if fructose replaces glucose as the carbohydrate source (45). Our observation that fasting can also restore cholesterol levels in a carbohydrateinduced individual would appear to support this view.

To date, the electron microscope has been used relatively little in the study of lipoprotein physiology and pathophysiology in man. Nevertheless, it may become an increasingly important tool in such investigations since it both provides a unique means of evaluating certain aspects of lipoprotein metabolism within the liver cell and offers a rapid method for evaluating particle size in plasma. For instance, it is not known whether certain types of endogenous hypertriglyceridemia, e.g. Type IV hyperlipoproteinemia, are primarily due to an overproduction or underutilization of triglyceride. Iso-

${ }^{9}$ Jones, A. L., D. Hamilton, N. Ruderman, and E. Shafrir. Data in preparation. 
topic studies of triglyceride turnover have frequently yielded conflicting results $(6,9,46,47)$. Furthermore, it has been suggested that certain instances of decreased triglyceride removal may be secondary to increased triglyceride production $(48,49)$. The findings presented here and those of other recent morphologic investigations $(42-43,5051)$ suggest that the electron microscope may be helpful in solving this problem since increased rates of hepatic VLDL production can probably bo detected by the presence of greater numbers of and/or larger lipoprotein particles in hepatocyte organelles.

\section{ACKNOWLEDGMENTS}

We are indebted to Mary Fleming, Edward Miller, and Zenta Skulte for their technical assistance; to Dr. Ray Gleason for his assistance in setting up the computer programs, and to Dr. George F. Cahill, Jr., for helpful criticism of the manuscript. We also acknowledge the invaluable aid of Mary Ellen Collins and Ruth Rogers, who assisted in the dietary regulation of the patients.

This work was supported in part by United States Public Health Service Grants AM-5077, AM-9584, and GM-06729.

\section{REFERENCES}

1. Ahrens, E. H., Jr., J. Hirsch, K. Oette, J. W. Farquhar, and Y. Stein. 1961. Carbohydrate-induced and fat-induced lipemia. Trans. Ass. Amer. Physicians Philadelphia. 74: 134.

2. Hatch, F. T., L. L. Abell, and F. E. Kendall. 1955. Effects of restriction of dietary fat and cholesterol upon serum lipids and lipoproteins in patients with hypertension. Am. J. Med. 19: 48.

3. Antonis, A., and I. Bersohn. 1961. The influence of diet on serum triglycerides in South African white and Bantu prisoners. Lancet. 1: 3 .

4. Knittle, J. L., and E. H. Ahrens, Jr. 1964. Carbohydrate metabolism in two forms of hyperglyceridemia. I. Clin. Invest. 43: 485 .

5. Farquhar, J. W., A. Frank, R. C. Gross, and G. M. Reaven. 1966. Glucose, insulin and triglyceride responses to high and low carbohydrate diets in man. J. Clin. Inv'st. 45 : 1648.

6. Reaven, G. M., R. L. Lerner, M. P. Stern, and J. W Farquhar. 1967. Role of insulin in endogenous hypertriglyceridemia. J. Clin. Ini'cst. 46: 1756

7. Bierman, E. L., and J. T. Hamlin, III. 1961. The hyperlipemic effect of a low-fat, high carbohydrate diet in diabetic subjects. Diabetes. 10: 432.

8. Salans, L. B., and G. M. Reaven. 1966. Effect of insulin pretreatment on glucose and lipid metabolism of liver slices from normal rats. Proc. Soc. Exp. Biol. Med. 122 : 1208.

9. Reaven, G. M., D. B. Hill, R. C. Gross, and J. IV. Farquhar. 1965. Kinetics of triglyceride turnover of very low density lipoproteins of human plasma. J. Clin. Ini'est. 44: 1826.

10. Nikkila, E. A., and K. Ojala. 1966. Acute effects of fructose and glucose on the concentration and removal rate of plasma triglyceride. Liff. Sci. 5: 89.
11. Fredrickson, D. S., K. Ono, and I.. L. Davis. 1963. Lipolytic activity of post-heparin plasma in hyperglyceridemia. J. Lipid Res. 4: 24.

12. Ruderman, N. B., K. C. Richards, V. Valles de Bourges, and A. L. Jones. 1968. Regulation of production and release of lipoprotein by the perfused rat liver. J. Lipid Res. 9: 613 .

13. Ruderman, N., A. Jones, R. Krauss, and E. Shafrir. 1969. The mechanism of increased hepatic triglyceride release in carbohydrate induced hyperlipemia. Clin. Res. $17: 261$.

14. Biale, Y., and E. Shafrir. 1969. Lipolytic activity toward tri- and monoglycerides in postheparin plasma. Clin. Chim. Acta. 23: 413

15. Chiamori, N., and R. J. Henry. 1959. Study of the ferric chloride method for determination of total cholesterol and cholesterol esters. Am. J. Clin. Pathol. 31: 305.

16. Carlson, L. A. 1963. Determination of serum triglycerides. J. Atheroscler. Res. 3: 334.

17. Lees, R. S. and F. T. Hatch. 1963. Sharper separation of lipoprotein species by paper electrophoresis in albumin containing buffer. J. Lab. Clin. Med. 61: 518.

18. Fredrickson, D. S., R. I. Levy, and R. S. Lees. 1967. Fat transport in lipoproteins-An integrated approach to mechanisms and disorders. N. Engl. J. Med. 276: 34, $94,148,215,273$.

19. Soeldner, J. S., R. E. Gleason, R. F. Williams, M. J. Garcia, D. M. Beardwood, and A. Marble. 1968. Diminished serum insulin response to glucose in genetic prediabetic males with normal glucose tolerance. Diabetcs. $17: 17$.

20. Lowry, O. H., N. J. Rosebrough, A. L. Farr, and R. J. Randall. 1951. Protein measurement with the Folin phenol reagent. J. Biol. Chem. 193: 265.

21. Havel, R. J., H. A. Eder, and J. H. Bragdon. 1955. The distribution and chemical composition of ultracentrifugally separated lipoproteins in human serum. J. Clin. Iniest. 34: 1345.

22. Jones, A. L. and J. M. Price. 1968. Some methods of electron microscopic visualization of lipoproteins in plasma and chyle. J. Histochem. Cytochem. 16: 366.

23. Statist. Bull. Metrop. Life Ins. Co. 1959. 40: 3.

24. Skipski, V. P., M. Barclay, R. K. Barclay, V. A. Fetzer, J. J. Good, and F. M. Archibald. 1967. Lipid composition of serum lipoproteins. Biochem. J. 104: 340.

25. Cornwell, D. G., F. A. Kruger, G. J. Hamwi, and J. B. Brown. 1961. Studies on the characterization of human serum lipoproteins separated by ultracentrifugation in a density gradient. II. Serum lipoproteins in hyperlipemic subjects. Amer. J. Clin. Nutr. 9: 41.

26. Gustafson, A. 1966. Studies on human serum very-lowdensity-lipoproteins. Acta Med. Scand. Suppl. 446: 1.

27. Gustaf son, A., P. Alaupovic, and R. H. Furman. 1965. Studies of the composition and structure of serum lipoproteins: Isolation, purification, and characterization of very low density lipoproteins of kuman serum. Biochemistry. 4: 596.

28. Oncley, J. L., F. R. N. Gurd, and M. Melin. 1950. Preparation and properties of serum and plasma proteins. $\mathrm{XXV}$. Composition and properties of human serum B-lipoprotein. J. Amer. Chem. Soc. 72: 458.

29. Vandenheuvel, F. A. 1962. The origin, metabolism and structure of normal human serum lipoproteins. Can. J. Biochem. 40: 1299.

30. Hayes, T. L., and J. E. Hewitt. 1957. Visualization of individual lipoprotein macromolecules in the electron microscope. J. Appl. Physiol. 11: 425. 
31. Forte, G. M., A. V. Nichols, and R. M. Glaeser. 1968. Electron microscopy of human serum lipoproteins using negative staining. Chem. Phys. Lipids. 2: 396.

32. Lindgren, F. T., and A. V. Nichols. 1960. Structure and Function of Human Lipoproteins. In Plasma Proteins. F. W. Putnam, editor. Academic Press Inc., New York. Vol. 2: 11.

33. Windmueller, H. G., and A. E. Spaeth. 1967. De Novo synthesis of fatty acid in perfused rat liver as a determinant of plasma lipoprotein production. Arch. Biochim. Biophys. 122: 362 .

34. Mahley, R. W., R. L. Hamilton, and V. S. Lequire. 1969. Characterization of lipoprotein particles isolated from the Golgi apparatus of rat liver. J. Lipid Res. 10: 433.

35. Lees, R. S., and D. S. Fredrickson. 1965. The differentiation of exogenous and endogenous hyperlipemia by paper electrophoresis. J. Clin. Invest. 44: 1968.

36. Bierman, E. L., D. Porte, Jr., D. D. O'Hara, M Schwartz, and F. C. Wood, Jr. 1965. Characterization of fat particles in plasma of hyperlipemic subjects maintained on fat-free, high-carbohydrate diets. J. Clin. Invest. $44: 261$.

37. Baxter, J. H. 1966. Origin and characteristics of endogenous lipid in thoracic duct lymph in rat. J. Lipid Res. 7: 158 .

38. Franks, J. J., E. M. Riley, and K. J. Isselbacher. 1966. Synthesis of fatty acids by rat intestine in vitro. Proc. Soc. Exp. Biol. Med. 121: 322.

39. Windmueller, H. G., and R. I. Levy. 1968. Production of $\beta$-lipoprotein by intestine in the rat. J. Biol. Chem. 243: 4878 .

40. Ockner, R. K., F. B. Hughes, and K. J. Isselbacher. 1969. Very low density lipoproteins in intestinal lymph: Origin, composition, and role in lipid transport in the fasting state. J. Clin. Invest. 48: 2079.

41. Jones, A. L., N. B. Ruderman, and J. B. Emans. 1969. An electron microscopic study of hepatic lipoprotein syn- thesis in the rat following anti-insulin serum, nicotinic acid and puromycin administration. Gastroenterology. 56: 402.

42. Mahley, R. W., M. E. Gray, R. L. Hamilton, and V. S. LeQuire. 1968. Lipid transport in liver. II. Electron microscopic and biochemical studies of alterations in lipoprotein transport induced by cortisone in the rabbit. Lab. Invest. 19: 358.

43. Stein, O., and Y. Stein. 1965. Fine structure of the ethanol induced fatty liver in the rat. Israel J. Med. Sci. $1: 378$.

44. MacDonald, I. 1966. Lipid responses to dietary carbohydrates. Advan. Lipid Res. 4: 39.

45. Winitz, M., J. Graff, and D. A. Seedman. 1964. Effect of dietary carbohydrate on serum cholesterol levels. Arch. Biochem. Biophy's. 108: 576.

46. Ryan, W. G., and T. B. Schwartz. 1965. Dynamics of plasma triglyceride turnover in man. Metab. Clin. Exp. 14: 1243 .

47. Sandhofer, F., K. Bolzano, S. Sailer, and H. Braunsteiner. 1968. Die Verwendung von PlasmaglucoseKohlenstoff zur Bildung von Plasmatriglycerid-Glycerol bei Patienten mit primärer, "kohlenhydratinduzierter" Hypertriglyceridämie. Klin. Wochenschur. 46: 1034.

48. Persson, B., P. Bjorntorp, and B. Hood. 1966. Lipoprotein lipase activity in human adipose tissue. I. Conditions for release and relationship to triglycerides in serum. Metab. Clin. Exp. 15: 730 .

49. Shafrir, E., and Y. Biale. 1971. Effect of experimental hypertriglyceridemia on tissue and serum lipoprotein lipase activity. European J. Clin. Invest. In press.

50. Jones, A. L., N. B. Ruderman, and M. G. Herrera. 1967. Electron microscopic and biochemical study of lipoprotein synthesis in the isolated perfused rat liver. J. Lipid Res. 8: 429.

51. Hamilton, R. L., D. M. Regen, M. E. Gray, and V. S. LeQuire. 1967. Lipid transport in liver. I. Electron microscopic identification of very low density lipoproteins in perfused rat liver. Lab. Invest. 16: 305. 